\title{
EDITORIAL FOREWARD
}

DOI: $10.2478 /$ seeur-2019-0001

The Board of Editors is honored to present to you this edition of the SEEU Review, which appears in July 2019.

As is consistent with the intentions of the SEEU Review, this edition covers a broad range of scholarship from the main disciplines taught and studied at South East European University. The topics are admirably diverse, ranging from English Language Teaching classroom techniques to the political relationship between Kosovo and Spain; from civil laws in France to the position of the Albanian diaspora. We congratulate our various authors on their successful research, as reported herein.

All papers accepted for inclusion were recommended to the Editorial Board based upon blind reviewing, and the SEEU Review takes pride in never asking authors for any payment or compensation for their submission. All papers accepted are published free of any fee to their author(s). As predatory academic journals become ever more subtle in disguising their intentions, it remains a point of honor for the SEEU 
Review to maintain this clear standard: we do not charge our authors any fee, ever.

It should be noted that, as always, the SEEU Review accepts papers based upon the principle that the author is ultimately responsible for the intellectual content of the work. This journal accepts papers in good faith, and the scholarly responsibility for the appropriate recognition of sources and quotations rests with the author or authors identified.

Dr. Andrew Goodspeed Editor-in-Chief 